\title{
Ecofriendly Approach of Managing Onion Downy Mildew
}

\author{
Ankita $^{1}$, Sunita Chandel ${ }^{1}$, Manish Kumar ${ }^{2}$ and Vijay Kamal Meena ${ }^{3}$ \\ ${ }^{1}$ Department of Plant Pathology, Dr. Y. S. Parmar University of Horticulture \& Forestry, \\ Nauni, Solan, India \\ ${ }^{2}$ Department of Seed Science and Technology, Dr. Y. S. Parmar University of Horticulture \& \\ Forestry, Nauni, Solan, India \\ ${ }^{3}$ Division of Genetics, ICAR-Indian Agricultural Research Institute, New Delhi, India \\ *Corresponding author
}

\section{A B S T R A C T}

\section{Keywords}

Downy mildew, Eco-friendly, SAR chemicals, Botanicals, Bioagents

\section{Article Info}

Accepted:

17 November 2019 Available Online: 10 December 2019
Onion is one of the largely cultivated vegetable throughout India and grown as kitchen garden crop in Himachal Pradesh. The bulbs as well as seeds of crop are used in a variety of culinary preparations and holds high nutritive and medicinal value. The commercial cultivation of onion is very successful because of its high demand and market value. The major constraint faced in the cultivation of onions is the incidence of biotic and abiotic factors. Among the various factors inflicting gap in production level, downy mildew is one of the most threatening diseases in the state during the crop period causing heavy economic losses. It is caused by the oomycete Peronospora destructor (Berk.) Casp. ex Berk. which is one of the severely destructing pathogen that affects the crop at every growth stage. Hence, research experiment was carried out at the College of Horticulture, DR. YSPUHF, Nauni, Solan in 2017-18 cropping period to study the effect of SAR chemicals, botanicals and biocontrol agents against downy mildew disease of onion. The research experiment was conducted with 16 treatments with three replications. Treatments were applied before symptom appearance in case of SAR chemicals (3-4 leaf stage) and after symptom appearance in case of botanicals and biocontrol agents. Three sprays were given at 15 days interval, incidence and severity of the disease were recorded before first spraying and 7 days after each spraying using 0-9 scale given by Mohibullah for calculating per cent disease severity (PDS). In this study, the SAR chemical Chitosan (5 $\mathrm{mgl}^{-1}$ ) was found statistically superior to other treatments. Among botanicals Allium sativum (20\%) and Trichoderma viridae (0.8\%) among tested bio-agents was found superior.

\section{Introduction}

Onion is one of the most popular vegetable cultivated throughout India and grown as kitchen garden crop in Himachal Pradesh.
This vegetable is highly valued as vegetable as well as condiment all across the world. The bulbs are used in a variety of culinary preparations and possess high nutritive and medicinal value. It is rich in vitamin $\mathrm{C}$ and 
calcium. The commercial cultivation of onion is very successful because of its high demand and market value. In Himachal even though crop is grown as kitchen garden crop but it has the potential to become one of the commercial crop because of the favourable climate for bulb development. The major constraint faced in the cultivation of onion in subtropical and dry temperate zone is the incidence of diseases.

Among the various diseases inflicting onion, downy mildew is one of the most serious diseases in the state during the crop period leading to heavy crop losses. It is caused by the oomycete Peronospora destructor (Berk.) Casp. ex Berk. which is one of the most destructive pathogens that affects the crop in the field and at every stage of crop. It is damaging in dry humid climates where the pathogen thrives. The disease is known to affect plants at all stages. While the disease only infects foliage, a reduction in photosynthetic activity early in plant development results in curled, stunted plants and yield reduction. The disease is characterized initially by slightly pale spots which later developed into a light brown or purplish shade. As spots enlarge, often girdling of the leaves and a greyish violet furry mould develops on the spot's surface. Leaf areas are covered with white to greyish, cotton-like sporangia and sporangiophore. These "downy" masses are majorly noticed after rain or heavy dew and disappear soon after sunny weather resumes. As the progress of disease continues leaves may eventually turn crisp and brown and fall off. The pathogen produces aseptate hyaline and dichotomously branched mycelium, with variable size of sporangiophores. It produces hyaline sporangia, having pyriform or fusiform shape.

It can be managed well by chemicals (Agrios, 1997), but non-judicious use of pesticides will result in severe consequences like residual toxicity, environmental pollution, health hazards to human and other life forms, nonspecificity, resurgence and high cost. Thus, the obvious threats due to synthetic fungicides have resulted in a rethinking for the search of safer alternatives.

Plants have got several mechanisms to combat diseases caused by pathogens, mostly by preventing physical contact between plants and pathogens as well as through inducing innate defence mechanisms. Such synthetic elicitors can protect crops from diseases, without the need to be directly toxic for pathogenic organisms, they may also serve as promising alternatives to conventional biocidal pesticides, which often are harmful for the environment, farmers and consumers. The use of botanicals and bio-control agents for disease management is a very important area of research in present day. Naturally occurring plants has got several antimicrobial metabolites that can cause less human adversities and environmental impact. They have been proved as suitable substitutes for synthetic chemical pesticides. However, only $10 \%$ of the total plant species worldwide have been investigated for their pesticidal activities. Development of plant-based formulations is an important step to achieve their economical and effective use as pesticidal agents. The future strategy should be to identify and select plants with antimicrobial potential, conserve them to obtain sufficient quantity and to detect different standardization methods for development of pesticidal formulations and utilize them for eco-friendly and safe disease management without endangering life forms and environment. They are cost effective, safe, environment friendly and sustainable.

\section{Materials and Methods}

A field experiment with sixteen treatments including standard check and untreated control 
was laid out in Randomized Block Design in cropping season i.e. 2017-18 at the Pandah Research Farm of Department of Seed Science and Technology of Dr. Yashwant Singh Parmar University of Horticulture \& Forestry, Nauni, Solan, HP. A highly susceptible cv. "Paalam Lohit" was sown in plots $(2 \mathrm{x} 1 \mathrm{~m})$ during the last week of December.

Scoping experiments has lead to the selection of SAR chemicals, botanicals and bio-agents for this study. Preparation of plant extracts fresh leaves, scales or seeds (200 g) of each selected botanical were taken and then washed under tap water and grinded for 5 minutes in blender by adding small quantity of sterilized warm distilled water. After grinding, $200 \mathrm{ml}$ distilled water was added and homogenized in orbital shaker at $2000 \mathrm{rpm}$ for half an hour to get 100 per cent extract of plant parts. The plant material was then filtered through double-layered muslin cloth. Tyndallisation of the plant extracts were done in autoclave at 5 psi pressure for one hour for three consecutive days and then the extracts were kept in refrigerator for further use.

SAR chemicals were applied once at 3-4 leaf stage of the plant initially (without disease) and later the same plants were sprayed two times at 15 days interval, after the appearance of the disease. Whereas botanicals and bioagents were sprayed, immediately at their recommended concentration after the onset of the first disease symptoms under the field conditions with a total of 3 sprays applied at fortnight intervals. The observations were recorded on per cent disease severity at 7 days interval by following the scale of Mohibullah (1991) by examining the lesions on leaves based on 0-9 scale and bulb yield (kg/plot or $\mathrm{t} / \mathrm{ha}$ ) at the maturity of the crop i.e. at the time of harvesting. Ridomil Gold 68 WG (Mancozeb 64\% + Metalaxyl 4\%) @ 0.25\%, a commonly used fungicide was also used for comparison.
The PDI (per cent disease index) was calculated by using the formula given by Mc Kinney (1923).

Per cent disease index $(\mathrm{PDI})=$

Sum of all disease ratings $\mathrm{x} 100$

Total no. of ratings x Maximum disease grade

\section{Results and Discussion}

Field trials conducted during cropping season (2017-18) revealed that SAR chemicals has significantly reduced the severity of downy mildew in comparison to control and equally effective as compared to standard check i.e. Ridomil Gold 68 WG (\% disease severity). Maximum (82.39 \%) disease control was achieved in Chitosan with minimum disease severity of 6.6 per cent while in other effective treatments, the per cent disease control ranged between 64.92 to 80.75 per cent. Chitosan being maximum effective, possessed maximum growth, gave excellent control of disease and supported good bulb yield (1.73 $\mathrm{kg} / \mathrm{plot}$ ). But best yield level was obtained in Ridomil Gold (1.77kg/plot). Whereas overall Yeast followed by Bacillus subtilis were least effective in controlling the disease as well as increasing the yield factor. Hence, it is concluded from the results that the, Chitosan has not only checked the downy mildew to great extent but showed good ability in improving the bulb yield.

Chitosan nanoparticles have got higher degree of acetylation that induces resistance against pearl millet downy mildew owing to the production of nitric oxide generation (Siddaiah et al., 2018). Chitosan is an active inducer of defense responses against downy mildew disease and thus has the potential of becoming an alternative means of disease control (Sharathchandra et al., 2004). The 
activation of protective mechanisms in plant tissues with chitosan inhibited the growth of taxonomically different pathogens. It has been considered as an alternative to chemical fungicides. The efficiency of phosphite application in certain pathosystems is due to the fact that the plant has better assimilation in the presence of phosphorus and potassium, making it able to activate defence mechanisms and to produce phytoalexins, natural selfdefence substances that confer resistance against pathogens especially in grapevine downy mildew system. Phytogard $\left(\mathrm{K}_{2} \mathrm{HPO}_{3}\right)$ may constitute an alternative method to counter downy mildew of Brassicas (Nojosa et al., 2005). Phosphonate or potassium derivatives such as $\mathrm{K}_{2} \mathrm{HPO}_{4}$ or $\mathrm{KH}_{2} \mathrm{PO}_{4}$ induce SAR in different pathosystems. These compounds have similarities with $\mathrm{K}_{2} \mathrm{HPO}_{3}$ (Phytogard) but they seem to have different modes of action (Reuveni and Reuveni, 1998). Post-inoculation application of BABA was reported to induce resistance against downy mildew of grape and Phytophthora infestans, tobacco from Peronospora tabacina (Cohen, 2002).

Plots treated with fungicides has produced marketable onion bulb yield and it confirms that early defoliation of onion due to downy mildew has reduced bulb sizes and caused yield losses (Surviliené et al., 2008). The maximum yield in the fungicide treated plots may be due to the more number of leaves and less disease severity that indirectly contributes to the higher yields (Iqbal et al., 2009).

Among different plant extracts, A sativum, extract was statistically superior and reduced the downy mildew severity to 7.84 per cent followed by $A$ indica $(9.38 \%)$ while Bougainvillia (11.10\%) was next best in order and Aloe vera (12.59\%) was least effective. Maximum bulb yield was recorded in treatment with $A$ sativum $(1.6 \mathrm{~kg} / \mathrm{plot})$ followed by $A$ indica $(1.47 \mathrm{~kg} / \mathrm{plot})$ but both were statistically significant. Minimum yield was recorded in Aloe vera (1.2kg/plot).

The present study clearly demonstrated promising efficacy of botanicals like Allium and $A$ indica under protective spray programme, respectively. Botanicals, being eco-friendly with least residual toxicity can serve as a viable alternative to chemical fungicides. The affectivity of Allium sativum might be due to the presence of sulfur compounds like Aliin, Allicin, Ajoene, Allylpropl, Diallyl trisulfide, S -allylcysteine, Vinyldithiines, S-allylmercaptocystein and others compounds. The extracts from leaves or bulbs of various Allium species are effective against a large numbers of pathogens among that Peronosporas are one of them (Deepak et al., 2007).

Some plants are promising candidates for pearl millet downy mildew management like A. sativum and Azadirachta indica and they are well known plants as most of them are used for various medical purposes. Palenius $e t$ al., (2006) reported that Neem oil has multipurpose insecticide, miticide and fungicide property. Their utilization makes possible the efficient pest management exploiting the local natural resource base. Moreover, the costs of treatment are low and the contamination with residual amounts of pesticides can be avoided. Aloe and Bougainvillea extracts have been earlier employed in spray form for the management of downy mildew of maize (Kamalakannan and Shanmugam, 2009), downy mildew of grapes (Dagostin et al., 2010) and downy mildew of sorghum (Singh and Garampalli, 2012).

The interactions between Pseudomonas fluorescens and cucumber downy mildew disease caused by Pseudoperonospora cubensis has consequential changes on pathogenesis related (PR) proteins activity 
such as: Peroxidase (PO), $\beta$-1,3-glucanase (GLU) and Chitinase (CHI) because of that defensive responses are mediated by hypersensitivity reaction (HR), SA signal pathway and PR-proteins. Downy mildew of cucumber under green house conditions was controlled by $B$. subtilis spray (Abd El Moiety et al., 2003) (Table 1 and 2).

Table.1 Plants and parts used for aqueous extracts preparation for Botanicals

\begin{tabular}{|l|l|}
\hline Plants & Parts \\
\hline Azadirachta indica A. Juss & Young twigs without fruits \\
\hline Bougainvillia spectabilis Willd. & Young twigs \\
\hline Allium sativum L. & Bulb scales \\
\hline Aloe perfoliata var. vera L. & Whole plant(aerial) \\
\hline
\end{tabular}

Table.2 Effect of SAR and fungicides on onion downy mildew severity and bulb yield

\begin{tabular}{|l|l|c|c|c|}
\hline S.No. & \multicolumn{1}{|c|}{ Treatments } & $\begin{array}{c}\text { Disease severity } \\
(\mathbf{\%})\end{array}$ & $\begin{array}{c}\text { Disease control } \\
(\mathbf{\%})\end{array}$ & $\begin{array}{c}\text { Yield } \\
\text { (kg/plot) }\end{array}$ \\
\hline $\mathbf{1}$ & Potassium Orthophosphate & $7.07(15.4)$ & $80.75(64.35)$ & 1.6 \\
\hline $\mathbf{2}$ & Chitosan & $6.6(14.90)$ & $82.39(65.25)$ & 1.7 \\
\hline $\mathbf{3}$ & B amino butyric acid (BABA) & $9.50(17.94)$ & $75.13(59.90)$ & 1.6 \\
\hline $\mathbf{4}$ & Iso nicotinic Acid (INA) & $11.79(20.07)$ & $68.60(56.03)$ & 1.23 \\
\hline $\mathbf{5}$ & Benzothiadiazole (BTH) & $10.74(19.12)$ & $71.58(57.78)$ & 1.49 \\
\hline $\mathbf{6}$ & Acibenzolar S methyl (ASM) & $9.98(18.41)$ & $73.47(59.06)$ & 1.5 \\
\hline $\mathbf{7}$ & Bacillus subtilis & $12.7(20.89)$ & $66.24(54.53)$ & 1.6 \\
\hline $\mathbf{8}$ & Pseudomonas fluorescens & $10.47(18.87)$ & $71.26(58.24)$ & 1.4 \\
\hline $\mathbf{9}$ & Yeast & $13.02(21.15)$ & $64.91(54.05)$ & 1.23 \\
\hline $\mathbf{1 0}$ & Trichoderma viridae & $9.36(17.83)$ & $74.59(60.15)$ & 1.57 \\
\hline $\mathbf{1 1}$ & Allium sativum L.(Garlic) & $7.84(16.25)$ & $79.84(62.9)$ & 1.6 \\
\hline $\mathbf{1 2}$ & Azadirachta indica A. Juss (Neem) & $9.39(17.83)$ & $75.75(60.15)$ & 1.47 \\
\hline $\mathbf{1 3}$ & $\begin{array}{l}\text { Bougainvillia } \text { spectabilis } \\
\text { (Bougainvillea) }\end{array}$ & $11.10(19.46)$ & $69.22(57.16)$ & 1.5 \\
\hline $\mathbf{1 4}$ & Aloe perfoliata var. vera L. (Aloe) & $12.59(20.78)$ & $66.47(54.73)$ & 1.2 \\
\hline $\mathbf{1 5}$ & Mancozeb 64\% + Metalaxyl 4\% & $7.02(15.36)$ & $80.99(64.45)$ & 1.78 \\
\hline $\mathbf{1 6}$ & Ridomil Gold 60 WG & & & \\
\hline CD & & $37.82(37.9)$ & $0(0)$ & 0.97 \\
\hline & & 0.49 & 0.87 & 0.152 \\
\hline
\end{tabular}

ANOVA 01: DISEASE SEVERITY

\begin{tabular}{|l|r|r|r|r|r|}
\hline $\begin{array}{l}\text { Source of } \\
\text { Variation }\end{array}$ & DF & $\begin{array}{c}\text { Sum of } \\
\text { Squares }\end{array}$ & $\begin{array}{c}\text { Mean } \\
\text { Squares }\end{array}$ & $\begin{array}{c}\text { F- } \\
\text { Calculated }\end{array}$ & Significance \\
\hline Replication & 2 & 0.375 & & & \\
\hline Treatment & 15 & $1,265.63$ & 84.375 & 984.669 & \\
\hline Error & 30 & 2.571 & 0.086 & & \\
\hline Total & 47 & $1,268.57$ & & & \\
\hline
\end{tabular}


ANOVA 02: DISEASE CONTROL

\begin{tabular}{|l|r|r|r|r|r|}
\hline $\begin{array}{l}\text { Source of } \\
\text { Variation }\end{array}$ & DF & $\begin{array}{c}\text { Sum of } \\
\text { Squares }\end{array}$ & $\begin{array}{c}\text { Mean } \\
\text { Squares }\end{array}$ & $\begin{array}{c}\text { F- } \\
\text { Calculated }\end{array}$ & Significance \\
\hline Replication & 2 & 0.857 & & & \\
\hline Treatment & 15 & $10,447.87$ & 696.525 & $2,588.24$ & \\
\hline Error & 30 & 8.073 & 0.269 & & \\
\hline Total & 47 & $10,456.80$ & & & \\
\hline
\end{tabular}

ANOVA 03: YIELD LEVEL

\begin{tabular}{|l|r|r|r|r|r|}
\hline $\begin{array}{c}\text { Source of } \\
\text { Variation }\end{array}$ & DF & $\begin{array}{c}\text { Sum of } \\
\text { Squares }\end{array}$ & $\begin{array}{c}\text { Mean } \\
\text { Squares }\end{array}$ & \begin{tabular}{c}
\multicolumn{1}{c|}{ F- } \\
Calculated
\end{tabular} & Significance \\
\hline Replication & 2 & 0.03 & & & \\
\hline Treatment & 15 & 2.101 & 0.14 & 11.894 & \\
\hline Error & 30 & 0.353 & 0.012 & & \\
\hline Total & 47 & 2.484 & & & \\
\hline
\end{tabular}

The control of downy mildew on cucumber by the fungus $T$. harzianum under greenhouse conditions led to increase of both peroxidase and $\beta$-1, 3-glucanase activities. $P$. flourescens takes more time to establish around leaf colony as compared to Trichoderma viridae. (Singh and Rai, 2000)

It is concluded that the present investigation on Downy mildew of onion was undertaken with regards to its disease management through SAR chemicals, bio-control agents and botanicals. The results obtained are summarized as under: Result of present work indicates that some of the chemical elicitors, botanicals and bioagents are promising candidates for managing Onion downy mildew. Field trials conducted on disease management in the cropping period, with SAR chemicals revealed that among all the tested SAR chemicals, Chitosan was significantly most effective in reducing the severity of downy mildew to 6.6 per cent with 82.39 per cent disease control followed by Potassium phosphate $(7.07 \%, 80.75 \%)$. However, highest efficacy among biocontrol agent was reported with Trichoderma viridae by imparting 74.60 per cent disease control followed by Pseudomonas fluorescens (71.26 $\%)$ and Yeast (64.92\%) which possessed minimum level of disease control. Among the different bio-products, the Allium sativum has highest efficacy $(79.83 \%)$ against Peronospora destructor followed by A indica $(75.75 \%)$. The least effective botanicals were Aloe vera $(66.48 \%)$ and Bougainvillea (69.22\%).

SAR chemicals like Chitosan and Potassium phosphite are easily available but proper standardisation is required in terms of dosage and mode of application similarly Allium spp and $A$ indica are locally available as they are used by human for several purposes. Allium is a also seasoning agent. Biocontrol agents are already available in the standardised form in the market and are easier to apply.

\section{References}

Agrios GN. Plant Pathology. $2^{\text {nd }}$ edition. Academic Press, New York. 1997. 838 p.

Cohen Y. ß-aminobutyric acid induced resistance against plant pathogens. Plant Disease. 
2002.86: 448-457.

Dagostin S, Formolo T, Giovannini O, Pertot I and Schmitt A. 2010. Salvia officinalis extract can protect grapevine against Plasmopara viticola. Plant Dis. 2010.94:575-580.

Deepak SA, Gyula O, Syagadadu GS, Shetty NP, Shetty HS and Sheena S. Antisporulant activity of leaf extracts of Indian plants against Sclerospora graminicola causing downy mildew disease of pearl millet. Archives of Phytopathology and Plant protection. 2007. 38(1): 31-39.

Iqbal M, Sahi GM, Tahir HAS, Sahi ST and Atif M. Evaluation of different fungicides against downy mildew of onion. Pakistan journal of phytopathology. Academia edu.2009. 27:175-179.

Kamalakannan A and Shanmugam V. Management approaches of maize downy mildew using biocontrol agents and plant extracts. Acta Phytopathol Entomol Hung. 2009. 44:255-266

McKinney HH. Influence of soil temperature and moisture on infection of wheat seedling by Helminthosporium sativum. Journal of Agricultural Research. 1923. 26: 195-217.

Mohibullah Studies on Major Diseases of Bulb Vegetables (onion and garlic) in N.F.W.P. Province, Pakistan: Final Technical Report (October 1986 to September 1991). Agricultural Research Institute, Tarnab (Peshawar), N.W.P. Pakistan. 1991. 55p.

Nojosa, GBA, Resende MLV, Resende AV. Uso de fosfitos e silicatos na indução de resistência. In: Indução de resistência em plantas a patógenos e insetos (Cavalcanti L and Resende AV eds). Piracicaba.2005. pp.236-263.

Palenius HG, Hopkins D and Cantliffe DJ. Powdery mildew of cucurbits in Florida. 2006. S HS1067, Horticultural Sciences Department, Florida Cooperative Extension Service, Institute of Food and Agricultural Sciences, University of Florida.

Sharathchandra RG, Niranjan Raj S, Shetty NP, Amruthesh KN and Shekar Shetty H.A chitosan formulation Elexa induces downy mildew disease resistance and growth promotion in pearl millet. Crop Protection. 2004. 23: 881-888.

Siddaiah CN, Prasanth KVH, Satyanarayana NR, Mudili V, Gupta VK, Kalagatur NK, Satyavati T, Dai XF, Chen J, Mocan A, Singh BP and Srivastava RK. Chitosan nanoparticles having higher degree of acetylation induce resistance against pearl millet downy mildew through nitric oxide generation. Scientific Reports. 2018. $8: 2485$.

Singh H and Garampalli R H. Screening of plant extracts for organic management of downy mildew of sorghum. Archives Of Phytopathology And Plant Protection. 2012; 45:14, 1732-1740.

Surviliené E, Valiskaité A and Raudonis L. The effect of fungicides on the development of downy mildew of onions. Zemdirbyste Agriculture. 2008. 95: 171-179.

\section{How to cite this article:}

Ankita, Sunita Chandel, Manish Kumar and Vijay Kamal Meena. 2019. Ecofriendly Approach of Managing Onion Downy Mildew. Int.J.Curr.Microbiol.App.Sci. 8(12): 2474-2480. doi: https://doi.org/10.20546/ijcmas.2019.812.291 